\title{
Modelling and Optimization of Photovoltaic Serpentine Type Thermal Solar Collector With Thermal Energy Storage System For Hot Water and Electricity Generation For Single Residential Building
}

\section{Srimanickam Baskaran}

Veltech: Vel Tech Rangarajan Dr Sagunthala R\&D Institute of Science and Technology

Christopher Sathiya Satchi ( $\square$ christophersathya@gmail.com )

Anna University Chennai

\section{Saranya Amirtharajan}

Vel Tech Dr RR and Dr SR Technical University: Vel Tech Rangarajan Dr Sagunthala R\&D Institute of

Science and Technology

Metilda Manuel Swami Durai

Saveetha University Saveetha Engineering College

\section{Research Article}

Keywords: nominal operating cell temperature, TRNSYS, solar photovoltaic, forced circulation, solar fraction

Posted Date: October 21st, 2021

DOl: https://doi.org/10.21203/rs.3.rs-936955/v1

License: (c) (1) This work is licensed under a Creative Commons Attribution 4.0 International License. Read Full License 


\section{Abstract}

Increasing surface temperature significantly affects the electrical performance of photovoltaic (PV) panels. A closed-loop forced circulation serpentine tube design of cooling water system is used to effectively manage the surface temperature of PV panels. A real-time experiment was first carried out with a PV panel with a cooling system at HTF flow rates of $60 \mathrm{~kg} \mathrm{~h}^{-1}, 120 \mathrm{~kg} \mathrm{~h}^{-1}$, and $180 \mathrm{~kg} \mathrm{~h}^{-1}$. Based on the experimentation, a correlation for a nominal operating cell temperature (NOCT) and thermal efficiency for collector was developed for experimental validation of useful energy gained, cell temperature and electric power generation. The developed corrections are validated with electrical power and useful energy gained in photovoltaic serpentine thermal solar collector (PV/STSC) and fit into experimental results with a deviation of $1 \%$ and $2.5 \%$ respectively. Further, with the help of developed correlations, a system was developed in the TRNSYS tool through which an optimization study was performed based on electric and hot water demand. The findings indicate that an optimal system with an $8 \mathrm{~m}^{2}$ PV/STSC area, a HTF flow rate of $60 \mathrm{~kg} \mathrm{~h}^{-1}$, and TES system having a volume and height of $280 /$ and $0.8 \mathrm{~m}$ could meet $91 \%$ and 33 $\%$ of the hot water demand for Ac loads and $78 \%$ or DC loads, respectively.

\section{Introduction}

Energy consumption patterns, the greenhouse effect, the depletion of fossil fuel supplies and fossil fuel price fluctuation all contribute to an increase in the use of renewable resources in energy generation units (Pranesh et al., 2019). Solar power, on the other hand, is one of the most widely available clean energy sources. Solar energy is typically used to generate heat energy and electric energy using thermal collectors and PV systems. While the use of solar energy has grown, some limitations, such as high installation costs (Fakouriyan et al., 2019; Srimanickam et al., 2015), low energy conversion efficiency (Srimanickam et al., 2017; Srimanickam and Saranya, 2021) and the need for storage systems due to supply and demand curves that differ (S. Christopher et al., 2021; Thakur et al., 2020) have a negative impact on its use in comparison to other renewable energy sources. An enormous amount of research articles on photovoltaic/thermal (PV/T) technologies have been published in an attempt to resolve the above said barriers (Giwa et al., 2020; Lamnatou et al., 2021; Reji Kumar et al., 2020).

A PV/T technology can meet both electricity and heat energy demand simultaneously and reduces the amount of space needed for installation as compared to traditional solar energy systems (Saitoh et al., 2003). By lowering the PV panels surface temperature, a better conversion efficiency can be attained. Different HTF flow techniques achieved the reducing surface temperature of the solar panel. For instance, (Kluth, 2008) explored the advantages of water as a cooling agent. For this reason, two small solar panel models were made. One model was left uncooled, while the others were cooled by a fan blowing water on it. It was observed that a solar panel with water cooling produces more power production compared to another one. Moreover, cooling the solar panel surface by spraying water with a fan is inefficient because the water would not be spread over the entire panel surface, leaving certain areas of the PV panels uncooled, and this approach often results in a significant amount of water loss. To reduce the heat at the panel's surface, (Odeh and Behnia, 2009) used a surface cooling system. A water system was installed on 
the PV panel surface to deliver water sprinkling, and the study resulted in a $15 \%$ increase in production during the peak of solar radiation. For the months of June and December, (Bahaidarah, 2016) explored the cooling of a PV panel using jet impingement both experimentally and computationally. When compared to uncooled PV panels, the authors found that electric energy yield increased by $51.6 \%$ in June and $49.6 \%$ in December. (Eisapour et al., 2020) employed wavy tubes to investigate a PV/T collector's in terms of energy and exergy efficiency. The wavy tube improves energy and exergy efficiency by $6.06 \%$ and $4.25 \%$, respectively, compared to the straight tube. (Farahat, 2004) looked into the electrical efficiency of a PV/T system that used both direct water and heat pipe cooling. When compared to a direct water cooling system, it is demonstrated that the heat pipe cooling technology can help in achieving improved electrical efficiency. (Rahimi et al., 2015) examined single and multi-header micro configurations for PV cell cooling. PV panels with multiple header configurations eliminated more heat and generate more electricity, than PV panels with a single header design.

The performance of a PV/T collector can be improved by using the appropriate circulating fluid (Huaxu et al., 2020; Sheikholeslami et al., 2021). For instance, (Prakash, 1994) investigated the performance of $\mathrm{PV} / \mathrm{T}$ technology from two different circulating HTF viz air and water. According to the finding, when the water has been used as a cooling fluid, the thermal efficiency varied between $50 \%$ and $67 \%$. As cooling water is replaced with cooling air, the enhancement ranges from $17 \%$ to $51 \%$. (Hissouf et al., 2020) investigated the effects of dispersed copper in pure water on PV/T collector. The electrical efficiency of copper nanomaterial dispersed in water improved by $1.9 \%$ having a volume concentration of $2 \mathrm{wt} \%$ when compared to pure water result. The efficiency of a PV/T module using brine as the circulating coolant HTF was evaluated by (Saitoh et al., 2003). When the brine temperature was kept constant, the $\mathrm{PV} / \mathrm{T}$ conversion efficiency increased as $10 \%$ to $13 \%$, and the brine temperature at the outflow increased from $20^{\circ} \mathrm{C}$ to $40^{\circ} \mathrm{C}$ and the photo-thermal efficiency seems to be between $40 \%$ and $50 \%$. In addition to the previous research, various numerical and experimental investigations were performed to reduce the surface temperature of PV using nanofluids as a coolant to improve energy efficiency and output power. (Al-Shamani et al., 2016; Al-Waeli et al., 2017; Bianco et al., 2018; Hjerrild et al., 2016; Sardarabadi and Passandideh-Fard, 2016; Yazdanifard et al., 2017).

Water has been shown to be more effective as a coolant in PV/T than air. Adding nano / micro additives in the coolant could enhance the conversion efficiency in the PV technology (Said et al., 2021, 2018). However, dispersing the particle for a large quantity of coolant HTF (water) is not practically and economically feasible. From the literature, it is understood that most of the experiments were conducted using the solar simulator as an energy source. PV panel's effect is varied based on solar radiation, surface temperature, and other factors such as shading, dust, panel height from the ground, etc (Dwivedi et al., 2020). The influence of above said parameters could not be predicted in the simulator based experimental setup. By considering the above-enhanced cooling techniques that have been made for PV panel, in this paper, initially, a PV system was fabricated with a serpentine flow pattern for cooling. The main advantages of the serpentine flow pattern are the HTF can have a high heat removal factor $F_{R}\left(\eta_{0}\right)$ for low mass flow rate compared to other flow patterns for the same condition(S. S. Christopher et al., 
2021). Further, a fabricated PVT system is integrated with sensible TES for conducting a real-time experiment. A correlation was constructed for the PV/ STSC system based on the real time experimental data, and the proposed PVT system was created and modelled in TRNSYS, which is not available in the existence component type and validated with experimental data. Based on daily, monthly, and annual performance, the validated TRNSYS model is utilized to optimize the entire system to fulfil hot water and electricity requirements for a single residential building in Chennai.

\section{Description Of The Experimental Setup}

A photovoltaic serpentine thermal solar collector (PV/ STSC), TES tank, multimeter, temperature indicator, and pressure gauge are depicted in Fig. 1. A serpentine design copper absorber tube with nine passes was installed beneath the PV panel, as shown in Fig. 2. The PV/STSC system has external dimensions of $1640 \mathrm{~mm}$ in length, $992 \mathrm{~mm}$ in width, and $35 \mathrm{~mm}$ in height, with serpentine copper tube diameter and height of $6.35 \mathrm{~mm}$ and $1600 \mathrm{~mm}$, respectively. Table 1 shows the technical specifications of the PV panel tested in this study.

Stainless steel was used to construct a TES tank with an internal diameter of $300 \mathrm{~mm}$ and a height of $500 \mathrm{~mm}$. Glass wool insulation material with a thickness of $0.07 \mathrm{~m}$ was wrapped around the perimeter of the TES tank and connected pipes. PV/ STSC inlet and outlet were connected to a TES system's top and bottom. The flow rate of the HTF and inlet and outlet pressure difference of the PV/ STSC system was measured using rotameter (Acrylic Panel Type Flowmeter) and pressure gauge (NPC LPG Pressure Gauge Meter). A bypass flow line decreases the extra load on the pump during HTF circulation. A water of 35 I was filled in a TES tank. RTDs were put at the inlet and exit of the PV/STSC system to record the transient temperature fluctuation of HTF. On the other hand, the voltage and current were recorded by placing a multi-meter terminal in a solar PV panel. Every 30 minutes, the temperature of the HTF, as well as the current and voltage of the PV/STSC system were recorded. The experimental test facilities are located at the School of Mechanical Department, Vel Tech University, Chennai ((Latitude $13^{\circ} 00$ $29^{\prime \prime} N$ and Longitude $80^{\circ} 1306^{\prime \prime}$ E) as shown in Fig. 3.

The experiment was conducted in May 2020 by orienting the PV/STSC system East-West. When the charging experiment began, the cold water comes from the TES tank was sent to the inlet of the PV/ STSC collector. The HTF goes via a serpentine copper absorber tube, where the water temperature progressively rises. The hot outlet HTF from the PV/ STSC collector flow through the top of the TES system. The hot HFT flows from the top, increases the occupied water temperature by mixing in the TES tank. The HTF from the TES tank was retro into the solar collector's inlet for the subsequent charging cycles. The pyranometer (Kipp and Zonen - CMP 3) and Tru Track anemometer was used to record the global solar radiation and wind velocity.

Table 1 Technical specification of PV panel. 


\begin{tabular}{|ll|}
\hline Specification & Values \\
\hline $\mathrm{P}_{\mathrm{p}}$ & $260 \mathrm{~W}$ \\
\hline $\mathrm{V}_{\mathrm{mp}}$ & $30.18 \mathrm{~V}$ \\
\hline $\mathrm{I}_{\mathrm{mp}}$ & $7.96 \mathrm{~A}$ \\
\hline $\mathrm{V}_{\mathrm{oc}}$ & $36.72 \mathrm{~V}$ \\
\hline $\mathrm{I}_{\mathrm{sc}}$ & $8.99 \mathrm{~A}$ \\
\hline $\mathrm{T}_{\mathrm{Ic}}$ & $0.045 \% \mathrm{~K}^{-1}$ \\
\hline Single cell dimension & $156 \mathrm{~mm} \times 156 \mathrm{~mm}$ \\
\hline Single module dimension & $1640 \mathrm{~mm} \times 992 \mathrm{~mm} \times 35 \mathrm{~mm}$ \\
\hline
\end{tabular}

\section{Data Reduction}

The Hottel-Whillier-Bliss equation states the efficiency of a PV/STSC collector is given below.

$\eta=\frac{Q_{u}}{G_{t} \times A_{p}}=F_{R}(\tau \alpha)-F_{R}\left(\mathrm{U}_{\mathrm{L}}\right) \frac{\left(\mathrm{T}_{i}-T_{a}\right)}{G_{t}}$

The solar fraction (SF) for the proposed system is given as (Kalogirou, 2014).

$S F=\frac{Q_{s}}{Q_{s}+Q_{A U X}}$

where $Q_{S}$ and $Q_{A U X}$ are the energy supplied by the TES system and the auxiliary heater's additional energy, respectively.

The auxiliary heaters energy balance is calculated as

$\mathrm{T}_{\mathrm{o}}=\frac{\mathrm{Q}_{\mathrm{max}} \eta_{\mathrm{htr}}+\mathrm{m}_{\mathrm{L}} \mathrm{C}_{\mathrm{pf}} \mathrm{T}_{\mathrm{i}}+\mathrm{UA} \mathrm{T}_{\mathrm{a}}-\frac{\mathrm{UA} \mathrm{T}_{\mathrm{i}}}{2}}{\mathrm{~m}_{\mathrm{L}} \mathrm{C}_{\mathrm{pf}}+\frac{\mathrm{UA}}{2}}$

where $Q_{m a x}$ is the electric heater maximum heating rate; $\square_{h t r}$ is the auxiliary heater efficiency. $T_{i}$ is the HTF inlet temperature, and UA is the overall loss coefficient between the heater and its surroundings during operation.

The equation for calculating the power generated by a PV panel is as follows: 
$p=p_{\text {peak }}\left(\frac{G_{t}}{1000}\right)-0.045\left(\left(\left[\frac{N O C T}{G_{\text {Tavg }}}\right] \times G_{t}+T_{\text {canb }}\right)-25\right)$

\section{Validation Of Experimentation 4.1 Thermal validation}

An experiment was conducted to determine the utility of $F_{R}(\tau a)$ and $F_{R}\left(U_{L}\right)$. PV/ STSC energy efficiency variations related heat loss parameter are explored experimentally with three HTF flow rates of $60 \mathrm{~kg} \mathrm{~h}^{-1}$, $120 \mathrm{~kg} \mathrm{~h}^{-1}$ and $180 \mathrm{~kg} \mathrm{~h}^{-1}$, and the results are provided below. The experiment was conducted between a time interval of 9.00 to $17.00 \mathrm{~h}$, during May as the seasonal temperature is highest in the entire year. Considering the geographical location of the experimental facility (Chennai, Tamil Nadu, India), the sun is at its highest point between 12:00 to 13:00 h. From 12:00 h to 13.00 h, the PV/STSC absorbs the most instantaneous solar light. All of the experiments were carried out on various days, with a significant difference in ambient temperature and solar radiation. The outlet HTF from the PV/STSC achieves a high of $77^{\circ} \mathrm{C}$ at $14 \mathrm{~h}$ for a mass flow rate of $60 \mathrm{~kg} \mathrm{~h}^{-1}$ (11-May-2020), and then begins to drop with a decrease in solar radiation as indicated in Fig. 4(a). Furthermore, a rise in solar irradiation and intake HTF temperature increased the PV/STSC temperature. The PV/STSC surface temperatures were more at the end of the trial than they were at the beginning. This is due to increase in ambient temperature in the afternoon and the higher HTF temperature in the TES system. Temperature profiles at different flow rates show similar trends, as seen in Fig. 4.

To evaluate solar collector performance, the parameters ' $\mathrm{F}_{\mathrm{R}} \mathrm{U}_{\mathrm{L}}$ ' and ' $\mathrm{F}_{\mathrm{R}}(\mathrm{\tau a})$ ' must be included in the TRNSYS model. Variation in the above-stated performance parameters are identified using the slope and intercept factor of the linear equation given Eqs. (1). A minimum of four sets of repeatability data with a minimum of four symmetry data are required before and after solar noontime, as per the ASHRAE 932003 guideline, to generate the collector efficiency graphs (Al-Kayiem and Lin, 2014). In the present study for finding ' $\mathrm{F}_{\mathrm{R}} \mathrm{U}_{\mathrm{L}}$ ' and ' $\mathrm{F}_{\mathrm{R}}(\mathrm{Ta})^{\text {', }}$ plots were drawn between the efficiency and heat loss parameter, the data is collected between $8.00 \mathrm{~h}-17.00 \mathrm{~h}$ with time steps of $1 \mathrm{~h}$ for two distinct days for three different flow rates as shown in Fig. 5. Based on the linear regression model, an average value of $4.34 \mathrm{~W} \mathrm{~m}^{-2} \mathrm{~K}^{-1}$ and 0.53 for ' $F_{R} U_{L}$ ' and ' $F_{R}(\tau a)$ ' is obtained for the thermal performance prediction of proposed PV/STSC in the TRNSYS model. Table 2 summarized the results in terms of ' $F_{R} U_{L}$ ' and ' $F_{R}(\tau a)$ ' at various test conditions.

\section{Table $2 F_{R} U_{L}$ and $F_{R}\left(\eta_{0}\right)$ for PVT system at a various mass flow rate}




\begin{tabular}{|c|c|c|c|}
\hline $\begin{array}{l}\text { Mass flow rates } \\
\left(\mathrm{kg} \mathrm{h}^{-1}\right)\end{array}$ & Experiment days & $F_{R}\left(\eta_{0}\right)$ & $\begin{array}{l}\mathrm{F}_{\mathrm{R}} \mathrm{U}_{\mathrm{L}} \\
\left(\mathrm{W} \mathrm{m}^{-2} \mathrm{~K}^{-1}\right)\end{array}$ \\
\hline \multirow[t]{2}{*}{60} & 11-May-20 & 0.49 & 3.9 \\
\hline & 12-May-20 & 0.51 & 3.3 \\
\hline \multirow[t]{2}{*}{120} & 13-May-20 & 0.54 & 4.72 \\
\hline & 14-May-20 & 0.54 & 4.33 \\
\hline \multirow[t]{3}{*}{180} & 15-May-20 & 0.59 & 6.02 \\
\hline & 16-May-20 & 0.51 & 3.82 \\
\hline & Average & 0.53 & 4.34 \\
\hline
\end{tabular}

The useful energy gain in the solar collector is compared with the existing experimental results in Fig. 6 to see if the transient simulation approach used for this work is consistent. With a total error of $1 \%$, the simulation results are proven to be in strong agreement with the given data. The findings, on the other hand, revealed that the mathematical model was precise enough to be employed in assessing the collector's thermal performance under various conditions.

\subsection{Electrical validation}

$T_{p v}-T_{a}$ effects for mass flow rates of $60 \mathrm{~kg} \mathrm{~h}^{-1}, 120 \mathrm{~kg} \mathrm{~h}^{-1}$, and $180 \mathrm{~kg} \mathrm{~h}^{-1}$ are shown in Fig. 7. It is observed from the graph that as the HTF flow rates increase from $60 \mathrm{~kg} \mathrm{~h}^{-1}$ to $180 \mathrm{~kg} \mathrm{~h}^{-1}$ there is a significant decrease between the panel and ambient temperature owing to a higher heat removal factor. The nominal operating cell temperature (NOCT) testing is conducted in an open-circuit, implying the PV/STSC was not attached to an external load. For finding NOCT values of PV with a cooling system, data is plotted between $T_{p v}-T_{a}$ vs solar radiation for various test conditions. $A$ linear regression line is drawn between the two above said parameters for obtaining a linear model. Using an average slope and intercept of ' $Y$ ' for various flow rates and adding an average ambient temperature correlates with the NOCT model for PV/STSC as shown in Eq. (5). The slope and ' $Y$ ' intercept values at various flow rates are given in Table 3

NOCT $=\left(0.0309 \times G_{t}\right)+15.02+T_{a m b}(5)$

Table 3 Value of $Y$-intercept and slope for $T_{p}-T_{a}$ vs solar radiation 


\begin{tabular}{|c|c|c|c|}
\hline $\begin{array}{l}\text { Mass flow rate } \\
\left(\mathrm{kg} \mathrm{h}^{-1}\right)\end{array}$ & Experiment days & $Y$ intercept & Slope \\
\hline \multirow[t]{4}{*}{60} & \multirow[t]{2}{*}{ 11-May-20 } & 47.04 & 0.00464 \\
\hline & & -20.164 & 0.0616 \\
\hline & \multirow[t]{2}{*}{ 12-May-20 } & 41.757 & 0.0012 \\
\hline & & -13.749 & 0.0543 \\
\hline \multirow[t]{4}{*}{120} & \multirow[t]{2}{*}{ 13-May-20 } & -16.85 & 0.0558 \\
\hline & & 47.105 & 0.0053 \\
\hline & \multirow[t]{2}{*}{ 14-May-20 } & -15.63 & 0.0558 \\
\hline & & 48.508 & 0.0051 \\
\hline \multirow[t]{5}{*}{180} & \multirow[t]{2}{*}{ 15-May-20 } & 49.435 & 0.0054 \\
\hline & & -16.951 & 0.0588 \\
\hline & \multirow[t]{2}{*}{ 16-May-20 } & 45.63 & 0.0064 \\
\hline & & -15.871 & 0.0571 \\
\hline & Average & 15.021 & 0.0309 \\
\hline
\end{tabular}

The developed NOCT correlation was used to calculation of PV/STSC power generation using Eq. (4) and compared the predicted panel temperature power with experimental power generation data for various test conditions. From Fig. 8, it is observed that the simulated results of temperature and power generated of the PV panel found good agreements with a deviation of $2.1 \%$ and $2.5 \%$ respectively. Further, an optimization study will be performed using TRNSYS to meet the hot water and electricity demands in household applications by considering the correlation of thermal and electrical model.

\section{Description Of Trnsys System}

Figure 9 depicts the TRNSYS flow circuit of the PV/STSC paired with stratified TES system. A modelled PV/STSC, stratified TES system, pump, pipelines, auxiliary heater, weather data, integrator, online plotter, printer, and reservoir are all included in the system. Cold HTF is converted to hot HTF by solar radiation captured by the PV/STSC system. Due to the cumulative collection of hot HTF in the TES system, stratification could occur within the storage tank. As a result, hot HTF which stays at the top level and cold water, is settled at the TES system's bottom level. Meanwhile, cold HTF is directed to the bottom portion of the TES system to take the hot water on the top layer to the auxiliary heater. While the cold HTF pumped at the bottom side of the TES system is retro into the PV/STSC to get heat up and again heated HTF from the solar collector is sent to the TES system. This process continues throughout the year to 
calculate the optimum design parameters for PV/STSC systems. The simulation is run with $0.25 \mathrm{~h}$ time steps and the mathematical method used in the study is a successive method.

\section{Hot Water And Electricity Demands}

Several factors can influence the hourly distribution of hot water and electricity consumption throughout the day. The rate of consumption varies depending on the season, family member, and day. Based on Amhed et al (Ahmed et al., 2016) and council on energy, weather, and water studies ("Urban Households Consumed Less Electricity During Lockdown in Some Parts of India I CEEW," n.d.), an average hot water and electricity consumption of $126 / d^{-1}$ and 18 units are distributed in a day, as shown in Fig. 10.

\section{Optimization Of The System Parameters 7.1 Effect of PV/STSC area}

Under the same weather conditions, the impacts of changing the collector's aperture area from $1.6 \mathrm{~m}^{2}$ to $9.6 \mathrm{~m}^{2}$ with an increase in step size of $1.6 \mathrm{~m}^{2}$ on solar fraction were computed, and the results are presented in Fig. 11. From the graph it is seen that replacing collector area from $1.6 \mathrm{~m}^{2}$ to $3.2 \mathrm{~m}^{2}$ increases the annual solar fraction to $39 \%$, replacement of the area from $3.2 \mathrm{~m}^{2}$ to $4.8 \mathrm{~m}^{2}$ increasing the annual solar fraction to $12.4 \%, 4.8 \mathrm{~m}^{2}$ to $6.4 \mathrm{~m}^{2}$ increasing its annual solar fraction to $4.0 \%, 6.4 \mathrm{~m}^{2}$ to 8 $\mathrm{m}^{2}$ increasing its annual solar fraction to $1.2 \%$ and $8 \mathrm{~m}^{2}$ to $9.6 \mathrm{~m}^{2}$ increasing it's an annual solar fraction to $0.013 \%$ respectively. When the solar fraction readings for various collector areas were compared, it was noted that as the collector area increased, the solar fraction increased as well. However, the value of solar fraction beyond the collector area of $8 \mathrm{~m}^{2}$ did not show any significant effect in solar fraction. Considering the space availability and affordability, the collector aperture area for the current study consider being $8 \mathrm{~m}^{2}$.

\subsection{Effect of HTF flow rates}

With a collector area of $8 \mathrm{~m}^{2}$, the computed results of the solar fraction at different flow rates of 30-210 $\mathrm{kg} \mathrm{h}^{-1}$ are presented in Fig. 12. It can be observed that increasing the HTF flow from $30 \mathrm{~kg} \mathrm{~h}^{-1}$ to $60 \mathrm{~kg}$ $\mathrm{h}^{-1}$ has the advantages of minimal heat loss and a significant increase in the solar fraction. Furthermore, increasing the mass flow rate beyond $60 \mathrm{~kg} \mathrm{~h}^{-1}$ reduces the desired solar fraction since the HTF from the solar collector's outlet temperature is rather low at higher flow rates. The HTF from the solar collector destratifies the HTF in the TES system and maintains a low HTF temperature from top to bottom of TES tank due to high flow rates. The HTF mass flow rate of $60 \mathrm{~kg} \mathrm{~h}^{-1}$, which yields the most favorable solar fraction, is recommended for future exploration based on the preceding description.

\subsection{Effect of TES geometry}


For an $8 \mathrm{~m}^{2}$ collector area with a mass flow rate of $60 \mathrm{~kg} \mathrm{~h}^{-1}$, Fig. 13-14 shows the fluctuation of system performance as a function of varying height with constant volume and constant volume with varying height. It is also considered that the TES system is also encased in glass fibres and having an overall loss coefficient of the TES system is $1.73 \mathrm{~W} \mathrm{~m}^{-2} \mathrm{~K}^{-1}$. As shown in Fig. 13, the solar fraction values increase as the height of the TES system increases from 0.2 to $0.8 \mathrm{~m}$, then this rate of increase in solar fraction decreases as the height of the TES system is greater than $0.8 \mathrm{~m}$. On other hand, it is observed that with the fixed height of the TES system, the volume is varied from 129 / to $450 \mathrm{l}$. It is seen from the plot that solar fraction increase from 129 / to 280 / and after 280 / to 430 / the solar fraction remains the same and further increase in volume from 430 / the solar fraction begins to decrease. In both situations, the decrease in the solar fraction is due to an increase in energy loss from the TES system to the atmosphere from their lateral surfaces compared to the energy collected in the TES system. From the above study, it is said that a TES height and volume of $0.8 \mathrm{~m}$ and 280 / is the optimal value that can have a greater solar energy utilization capacity compared to other values.

\section{Electricity Generation}

A single household consumes the daily average electric power usage of $18.376 \mathrm{kWh} \mathrm{d}^{-1}$ as given in Fig. 10. The optimal configuration of the PV panels is made from a 260 watt peak PV module. The monthly distribution of power generation from the PV panel is shown in Fig. 14. It is observed from the figure that the maximum power out from the PV panels is found higher during March, April and May. This is a beneficial feature in the PV panel owing to electricity demand is high in the summer due to the high cooling load. PV generator accounts for 51 \% of energy consumption without any conversion losses. While, considering the combined loss of battery and inverter, the PV electricity contribution to the household is around $33 \%$. The inverter conversion efficiency can be eliminated by using DC powered appliances. In general, the power consumed by the DC loads is approximately $56 \%$ lower than AC loads for the same work output. In the above said energy distribution for the household is taken for DC loads, the usage is reduced to $10.29 \mathrm{kWh} \mathrm{d}^{-1}$. In such a case, the proposed PV panel size can be considered only for battery conversion loss and it can contribute around $78 \%$ of electricity demand.

\section{Conclusion}

The electrical and thermal performance of PV/STSC coupled with the TES system is evaluated using TRNSYS under transient settings for an entire annual year. The system was optimized for a hot water demand of 129 / and an electricity demand of $18.376 \mathrm{kWh} \mathrm{d}^{-1}$. The experiments and TRNSYS values are validated and found a minimum deviation. The PV/STSC system with storage exhibit an annual solar fraction of 0.80 and no significant enhancement is found after $8 \mathrm{~m}^{2}$. By keeping the fixed collector area, the influence of HTF flow rates on the solar fraction is studied and optimized as $60 \mathrm{~kg} \mathrm{~h}^{-1}$. Further studies were performed by varying the volume and height of the TES system to optimize the geometries for maintaining maximum stratification effects. The optimized volume and height of $280 /$ and $0.8 \mathrm{~m}$ can help to reach the annual solar fraction of 0.91 . It's also predicted that the suggested system won't be able 
to cover $100 \%$ of a single household's hot water and electricity energy needs in a tropical country like India. Furthermore, the proposed system can be employed as a secondary energy source to reduce the cost of electricity.

\section{References}

1. Ahmed K, Pylsy P, Kurnitski J (2016) Hourly consumption profiles of domestic hot water for different occupant groups in dwellings. Sol Energy 137:516-530. https://doi.org/10.1016/j.solener.2016.08.033

2. Al-Kayiem HH, Lin SC (2014) Performance evaluation of a solar water heater integrated with a PCM nanocomposite TES at various inclinations. Sol Energy 109:82-92. https://doi.org/10.1016/j.solener.2014.08.021

3. Al-Shamani AN, Sopian K, Mat S, Hasan HA, Abed AM, Ruslan MH (2016) Experimental studies of rectangular tube absorber photovoltaic thermal collector with various types of nanofluids under the tropical climate conditions. Energy Convers Manag 124:528-542. https://doi.org/10.1016/j.enconman.2016.07.052

4. Al-Waeli AHA, Sopian K, Chaichan MT, Kazem HA, Hasan HA, Al-Shamani AN (2017) An experimental investigation of $\mathrm{SiC}$ nanofluid as a base-fluid for a photovoltaic thermal PV/T system. Energy Convers Manag 142:547-558. https://doi.org/10.1016/j.enconman.2017.03.076

5. Bahaidarah HMS (2016) Experimental performance evaluation and modeling of jet impingement cooling for thermal management of photovoltaics. Sol Energy 135:605-617. https://doi.org/10.1016/j.solener.2016.06.015

6. Bianco V, Scarpa F, Tagliafico LA (2018) Numerical analysis of the Al2O3-water nanofluid forced laminar convection in an asymmetric heated channel for application in flat plate PV/T collector. Renew Energy 116:9-21. https://doi.org/10.1016/j.renene.2017.09.067

7. Christopher S, Parham K, Mosaffa AH, Farid MM, Ma Z, Thakur AK, Xu H, Saidur R (2021) A critical review on phase change material energy storage systems with cascaded configurations. J Clean Prod. https://doi.org/10.1016/j.jclepro.2020.124653

8. Christopher SS, Santosh R, Ponrajan Vikram M, Prabakaran R, Thakur AK, Xu H (2021) Optimization of a solar water heating system for vapor absorption refrigeration system. Environ Prog Sustain Energy 40. https://doi.org/10.1002/ep.13489

9. Dwivedi P, Sudhakar K, Soni A, Solomin E, Kirpichnikova I (2020) Advanced cooling techniques of P.V. modules: A state of art. Case Stud Therm Eng 21:100674.

https://doi.org/10.1016/j.csite.2020.100674

10. Eisapour M, Eisapour AH, Hosseini MJ, Talebizadehsardari P (2020) Exergy and energy analysis of wavy tubes photovoltaic-thermal systems using microencapsulated PCM nano-slurry coolant fluid. Appl Energy 266:114849. https://doi.org/10.1016/j.apenergy.2020.114849 
11. Fakouriyan S, Saboohi Y, Fathi A (2019) Experimental analysis of a cooling system effect on photovoltaic panels' efficiency and its preheating water production. Renew Energy 134:1362-1368. https://doi.org/10.1016/j.renene.2018.09.054

12. Farahat MA (2004) Improvement the thermal electric performance of a photovoltaic cells by cooling and concentration techniques, in: 39th International Universities Power Engineering Conference, UPEC 2004 - Conference Proceedings. pp. 623-628

13. Giwa A, Yusuf A, Dindi A, Balogun HA (2020) Polygeneration in desalination by photovoltaic thermal systems: A comprehensive review. Renew Sustain Energy Rev. https://doi.org/10.1016/j.rser.2020.109946

14. Hissouf M, Feddaoui M, Najim M, Charef A (2020) Numerical study of a covered PhotovoltaicThermal Collector (PVT) enhancement using nanofluids. Sol Energy 199:115-127. https://doi.org/10.1016/j.solener.2020.01.083

15. Hjerrild NE, Mesgari S, Crisostomo F, Scott JA, Amal R, Taylor RA (2016) Hybrid PV/T enhancement using selectively absorbing Ag-SiO2/carbon nanofluids. Sol Energy Mater Sol Cells 147:281-287. https://doi.org/10.1016/j.solmat.2015.12.010

16. Huaxu L, Fuqiang W, Dong Z, Ziming C, Chuanxin Z, Bo L, Huijin X (2020) Experimental investigation of cost-effective ZnO nanofluid based spectral splitting CPV/T system. Energy 194:116913. https://doi.org/10.1016/j.energy.2020.116913

17. Kalogirou SA (2014) Solar Energy Engineering: Processes and Systems: Second Edition, Solar Energy Engineering: Processes and Systems: Second Edition. Elsevier Inc, https://doi.org/10.1016/C2011-007038-2

18. Kluth A (2008) Using water as a coolant to increase solar panel efficiency. in: California State Science Fair

19. Lamnatou C, Vaillon R, Parola S, Chemisana D (2021) Photovoltaic/thermal systems based on concentrating and non-concentrating technologies: Working fluids at low, medium and high temperatures. Renew Sustain Energy Rev. https://doi.org/10.1016/j.rser.2020.110625

20. Odeh S, Behnia M (2009) Improving photovoltaic module efficiency using water cooling. Heat Transf Eng 30:499-505. https://doi.org/10.1080/01457630802529214

21. Prakash J (1994) Transient analysis of a photovoltaic-thermal solar collector for co-generation of electricity and hot air/water. Energy Convers Manag 35:967-972. https://doi.org/10.1016/01968904(94)90027-2

22. Pranesh V, Velraj R, Christopher S, Kumaresan V (2019) A 50 year review of basic and applied research in compound parabolic concentrating solar thermal collector for domestic and industrial applications. Sol Energy. https://doi.org/10.1016/j.solener.2019.04.056

23. Rahimi M, Asadi M, Karami N, Karimi E (2015) A comparative study on using single and multi header microchannels in a hybrid PV cell cooling. Energy Convers Manag 101:1-8. https://doi.org/10.1016/j.enconman.2015.05.034 
24. Reji Kumar R, Samykano M, Pandey AK, Kadirgama K, Tyagi VV (2020) Phase change materials and nano-enhanced phase change materials for thermal energy storage in photovoltaic thermal systems: A futuristic approach and its technical challenges. Renew Sustain Energy Rev. https://doi.org/10.1016/j.rser.2020.110341

25. Said Z, Arora S, Bellos E (2018) A review on performance and environmental effects of conventional and nanofluid-based thermal photovoltaics. Renew Sustain Energy Rev. https://doi.org/10.1016/j.rser.2018.06.010

26. Said Z, Hachicha AA, Aberoumand S, Yousef BAA, Sayed ET, Bellos E (2021) Recent advances on nanofluids for low to medium temperature solar collectors: energy, exergy, economic analysis and environmental impact. Prog Energy Combust Sci. https://doi.org/10.1016/j.pecs.2020.100898

27. Saitoh H, Hamada Y, Kubota H, Nakamura M, Ochifuji K, Yokoyama S, Nagano K (2003) Field experiments and analyses on a hybrid solar collector. Appl Therm Eng 23:2089-2105. https://doi.org/10.1016/S1359-4311(03)00166-2

28. Sardarabadi M, Passandideh-Fard M (2016) Experimental and numerical study of metaloxides/water nanofluids as coolant in photovoltaic thermal systems (PVT). Sol Energy Mater Sol Cells 157:533-542. https://doi.org/10.1016/j.solmat.2016.07.008

29. Sheikholeslami M, Farshad SA, Ebrahimpour Z, Said Z (2021) Recent progress on flat plate solar collectors and photovoltaic systems in the presence of nanofluid: A review. J Clean Prod. https://doi.org/10.1016/j.jclepro.2021.126119

30. Srimanickam B, Saranya A (2021) Thermal Performance of Single Glazing Flat Plate Photovoltaic Thermal Hybrid System with Various Air Channels. J Test Eval 49:20170750. https://doi.org/10.1520/JTE20170750

31. Srimanickam B, Vijayalakshmi MM, Natarajan E (2017) Energy and Exergy Efficiency of Flat Plate PVT Collector With Forced Convection. J Test Eval 46:20160290. https://doi.org/10.1520/JTE20160290

32. Srimanickam B, Vijayalakshmi MM, Natarajan E (2015) Experimental Study of Exergy Analysis on Flat Plate Solar Photovoltaic Thermal (PV/T) Hybrid System. Appl Mech Mater 787:82-87. https://doi.org/10.4028/www.scientific.net/amm.787.82

33. Thakur AK, Vikrama MP, Christopher S (2020) Augmented Yield Productivity of Solar Still Using Energy Storage Materials: Experimental Investigation Under the Climatic Conditions of Rajasthan, in: Green Energy and Technology. Springer Science and Business Media Deutschland GmbH, pp. 817831. https://doi.org/10.1007/978-981-15-4246-6_51

34. Urban Households Consumed Less Electricity During Lockdown in Some Parts of India I CEEW [WWW Document], n.d. URL https://www.ceew.in/blogs/urban-households-consumed-less-electricityduring-lockdown-some-parts-india (accessed 5.14.21)

35. Yazdanifard F, Ameri M, Ebrahimnia-Bajestan E (2017) Performance of nanofluid-based photovoltaic/thermal systems: A review. Renew Sustain Energy Rev. https://doi.org/10.1016/j.rser.2017.03.025 
Figures

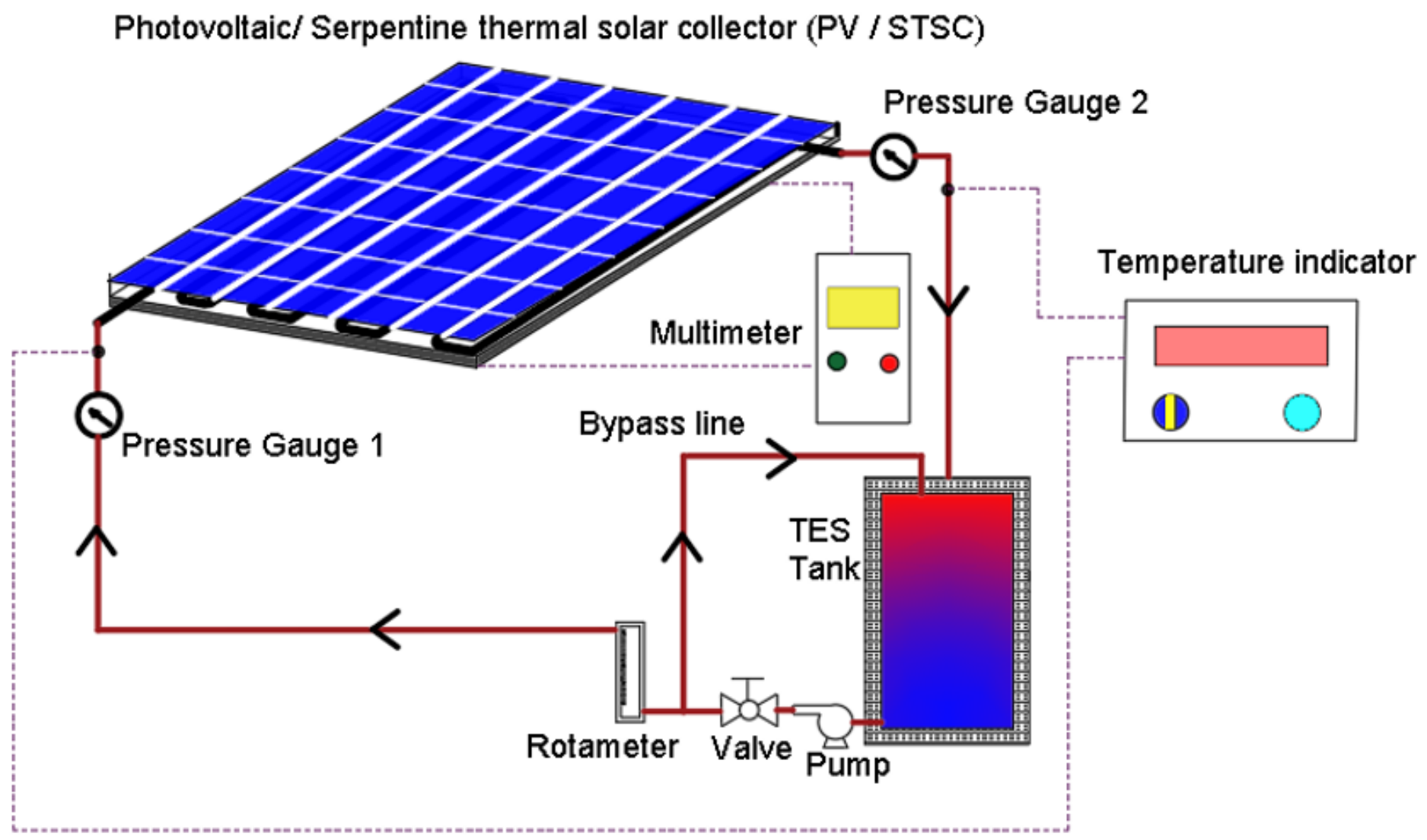

Figure 1

Experimental test facility system flow diagram 


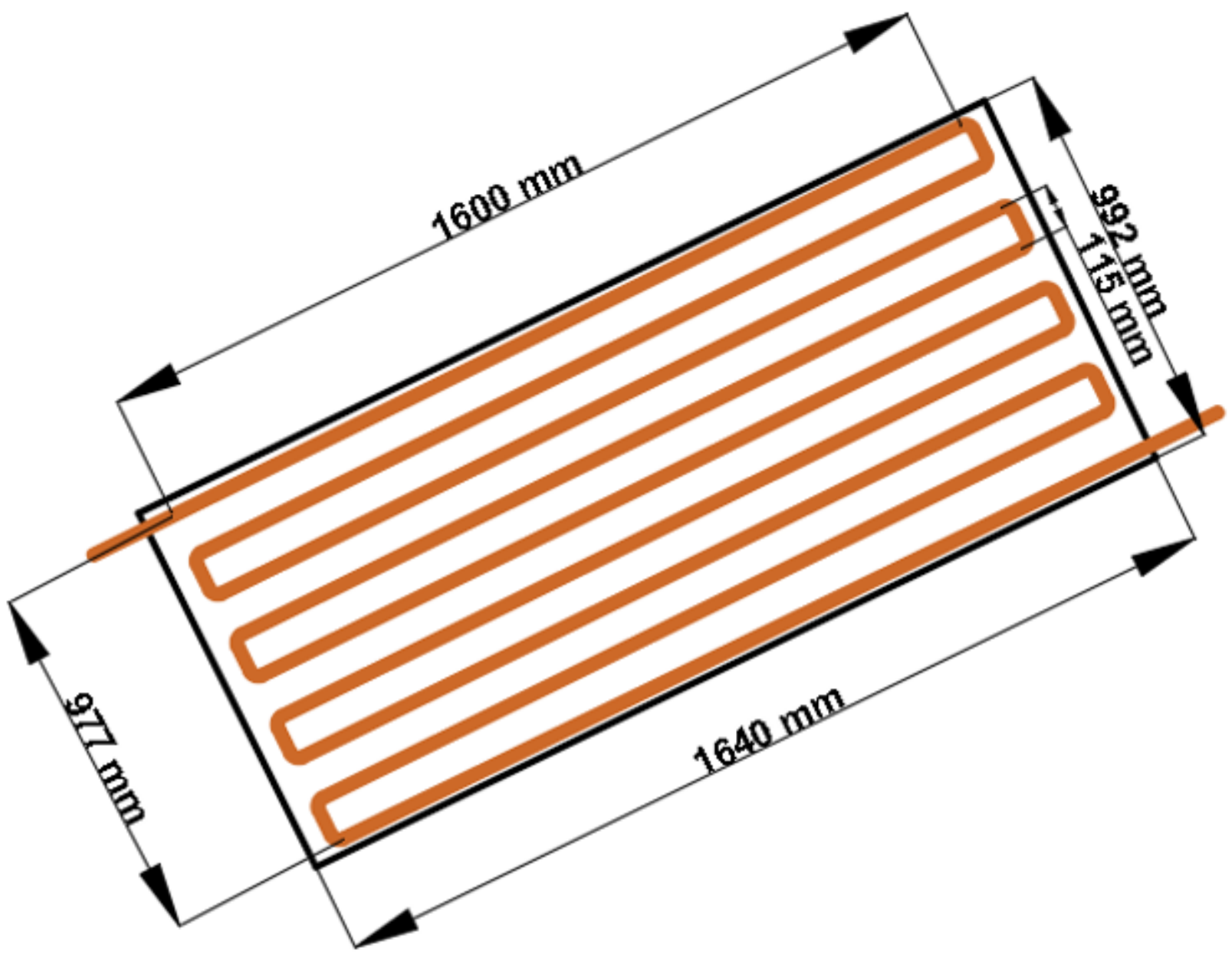

Figure 2

Schematic of HTF flow direction in a PV/STSC. 


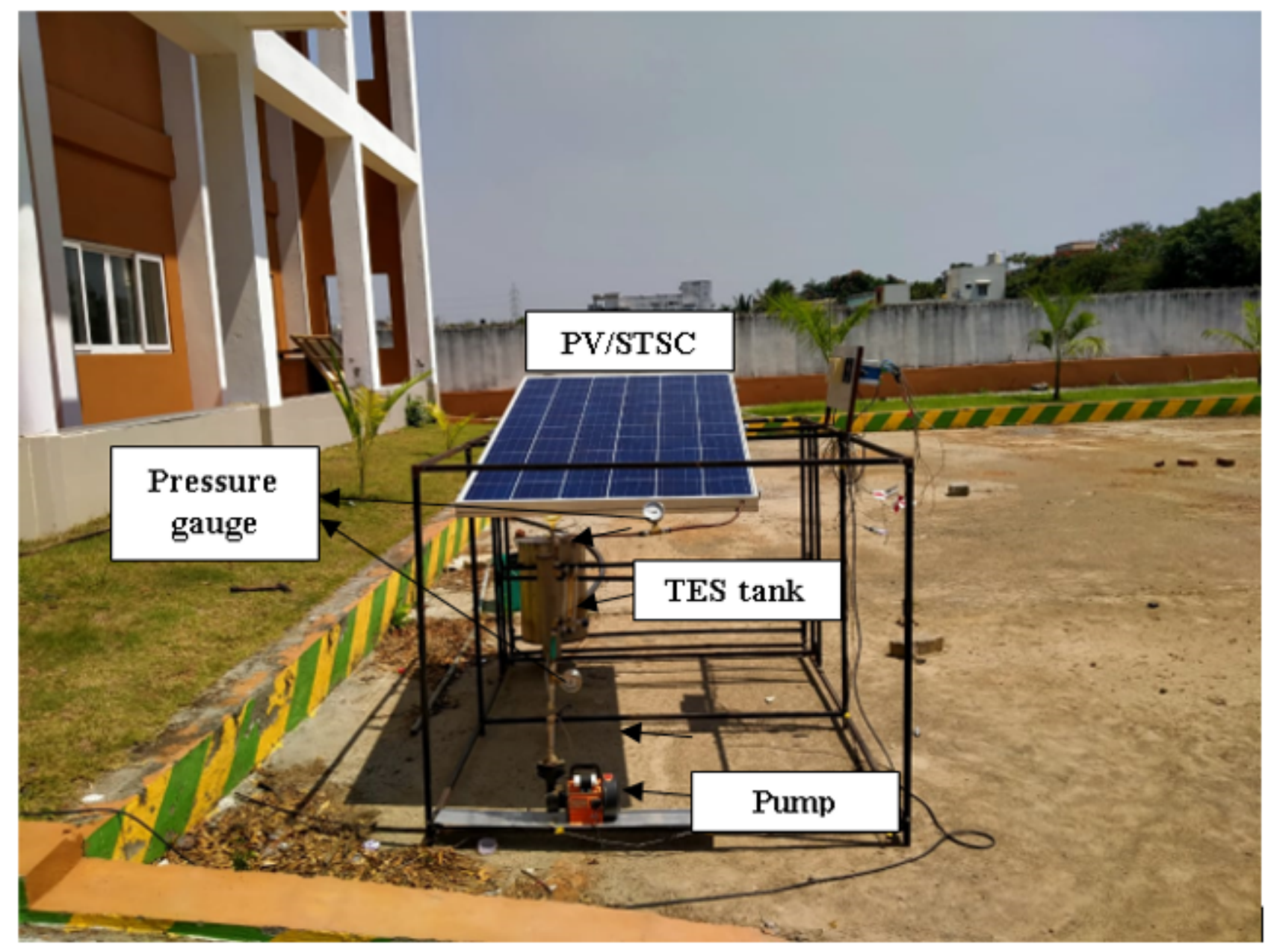

Figure 3

Photograph of the experimental test facility. 

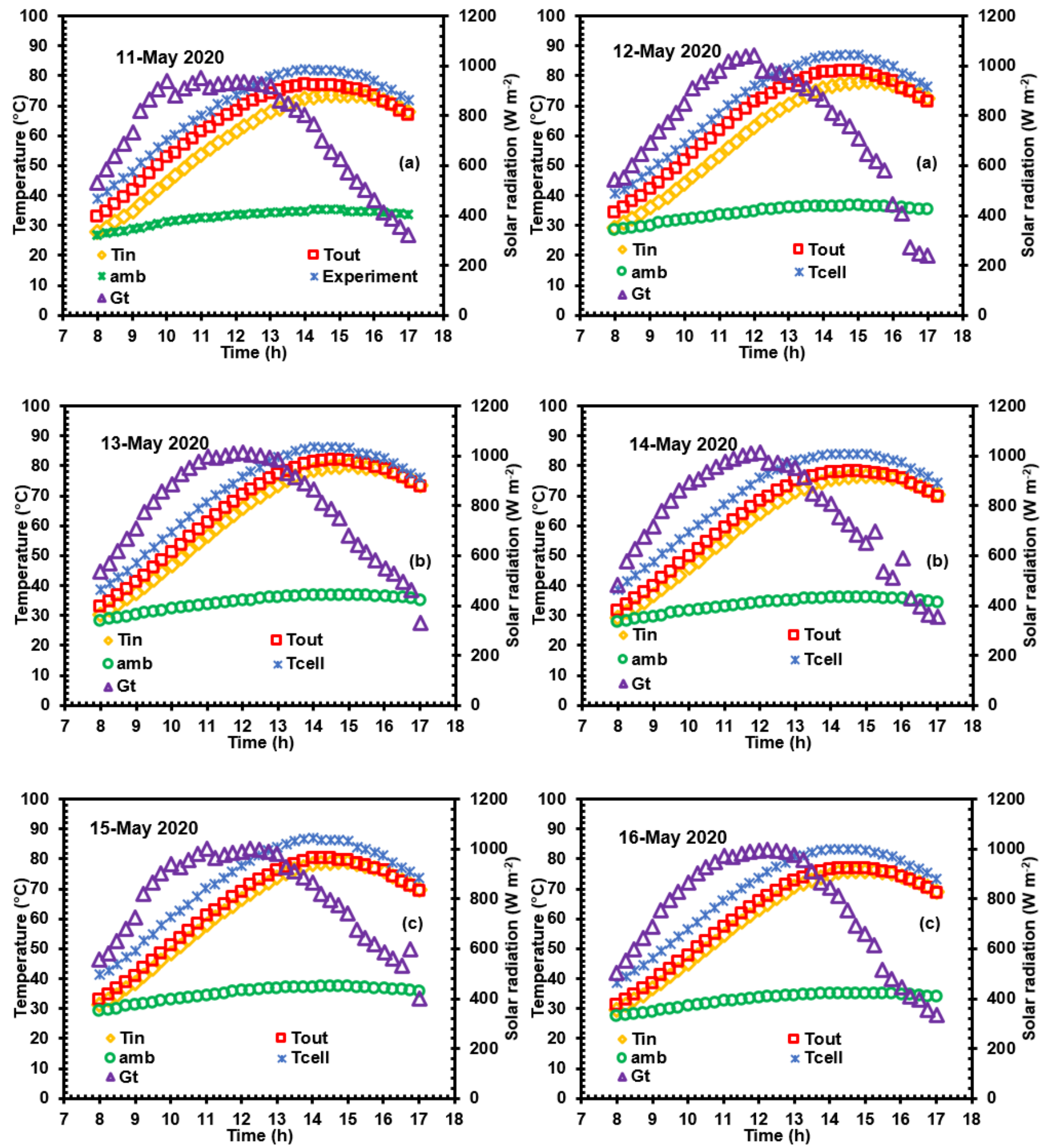

Figure 4

HTF temperature, ambient temperature and solar radiation for various days (a) $60 \mathrm{~kg} \mathrm{~h}-1$ (b) $120 \mathrm{~kg} \mathrm{~h}-1$ (c) $180 \mathrm{~kg} \mathrm{~h}-1$ 

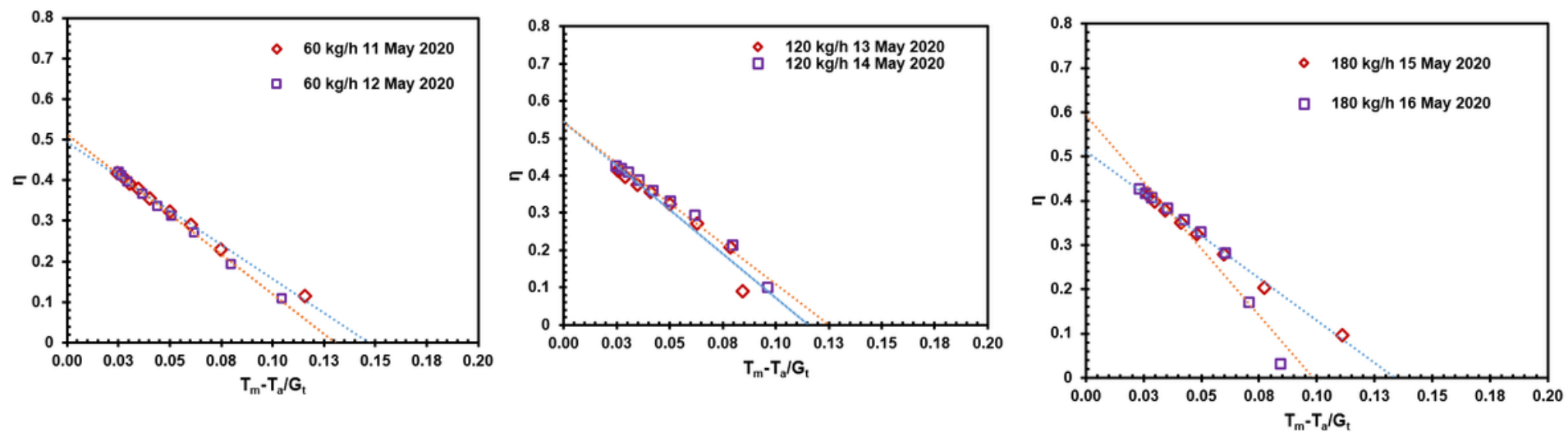

Figure 5

Efficiency of PVT for various mass flow rate.

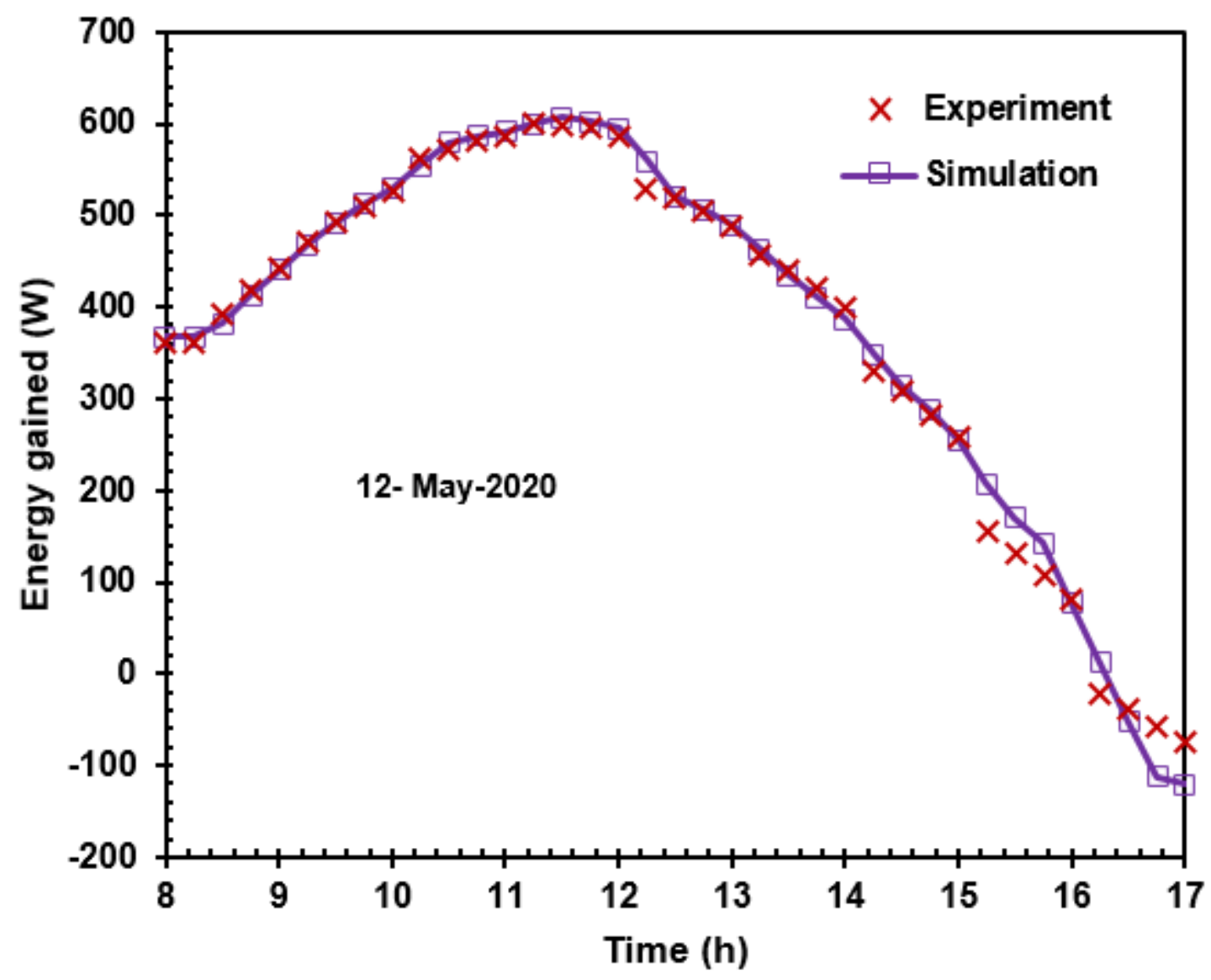

Figure 6

Comparisons of TRNSYS simulation results with experimental results 

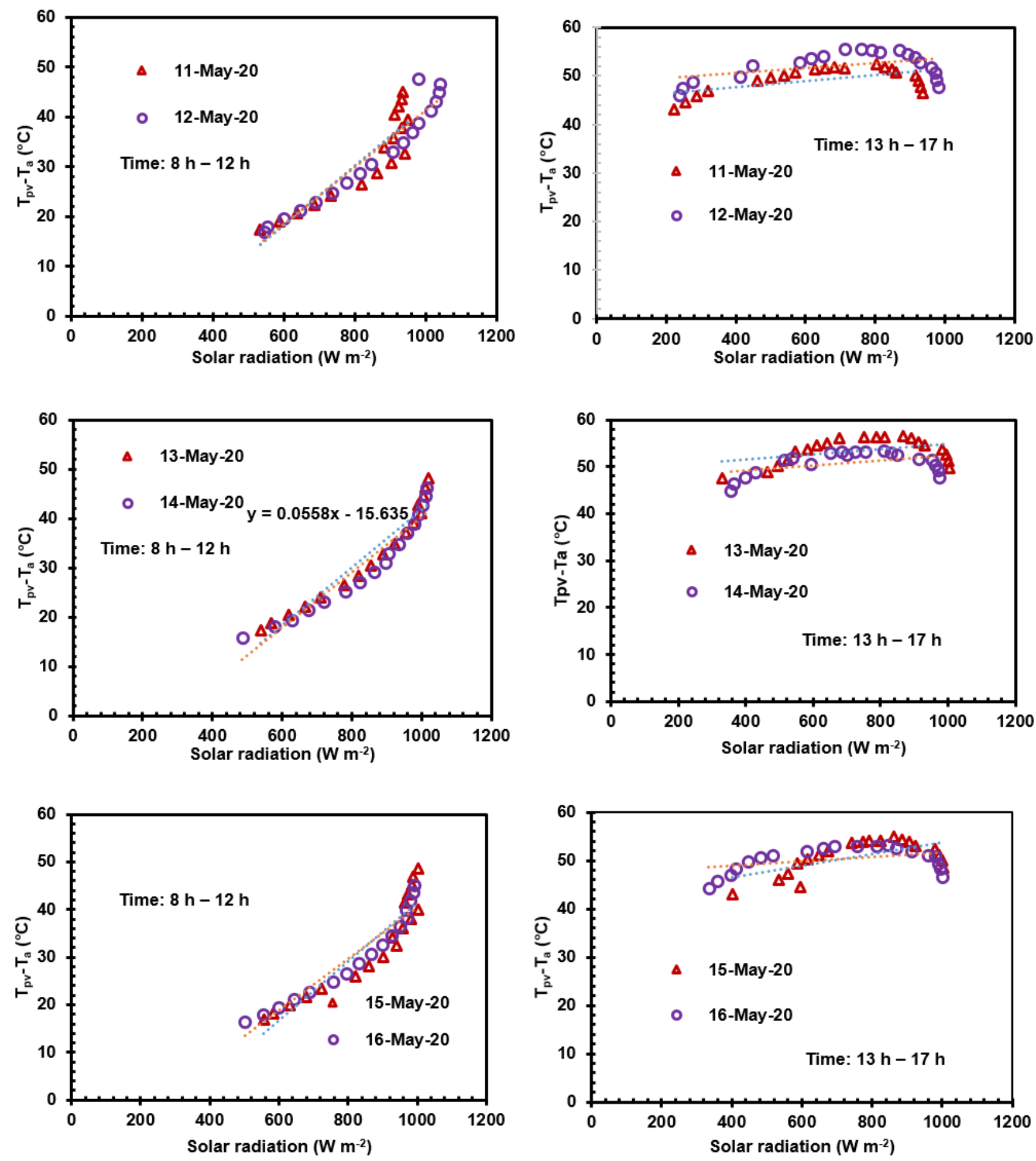

Figure 7

Variation of difference in panel temperature and ambient temperature vs solar radiation (a) $60 \mathrm{~kg} \mathrm{~h}-1$ (b) $120 \mathrm{~kg} \mathrm{~h}-1$ and (c) $180 \mathrm{~kg} \mathrm{~h}-1$ 

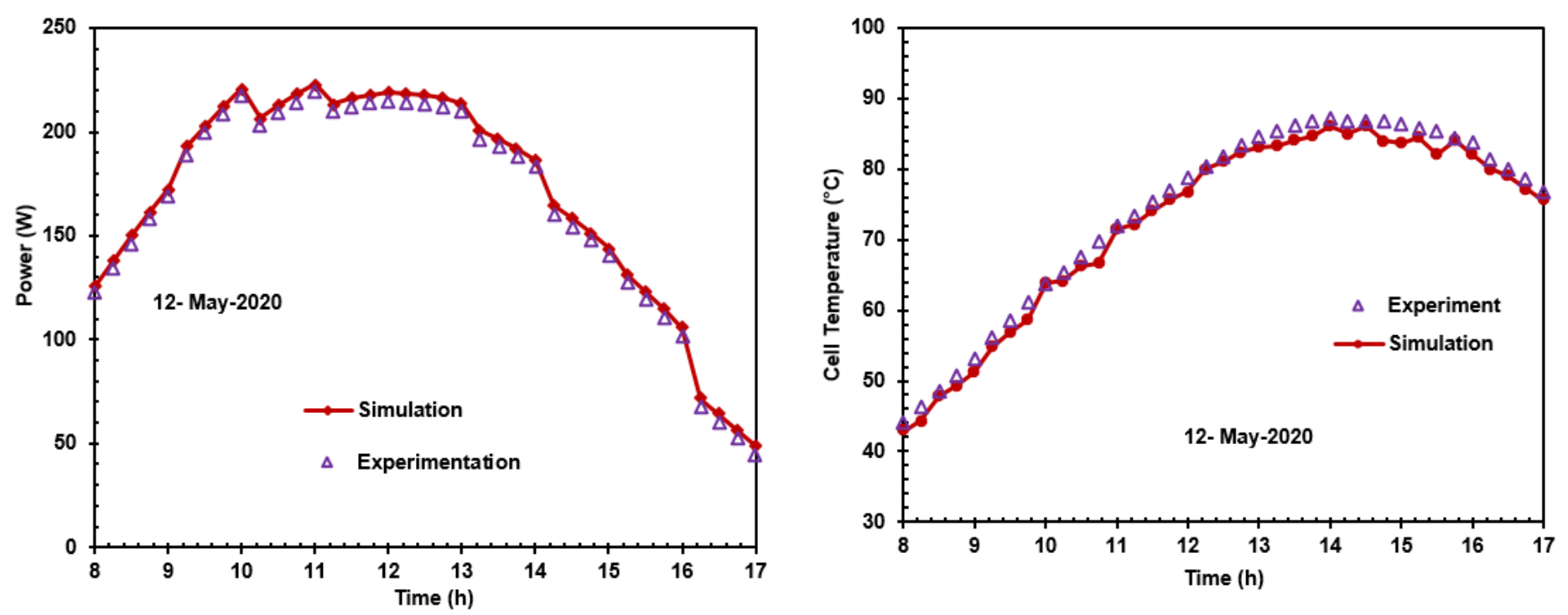

Figure 8

Comparison of PV power and temperature with simulated results for various test conditions

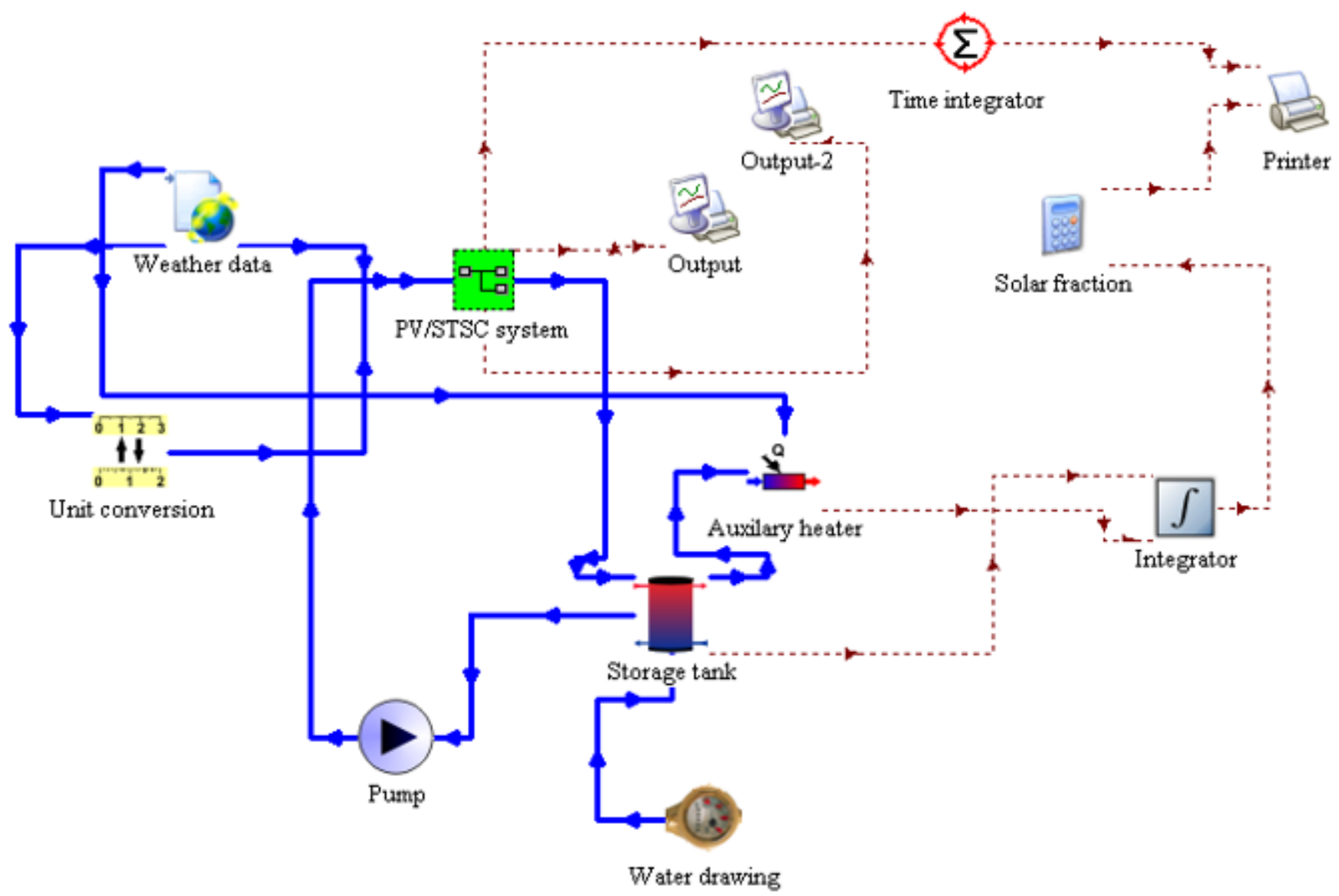

Figure 9

TRNSYS flow diagram of PV/STSC system integrated with TES system 


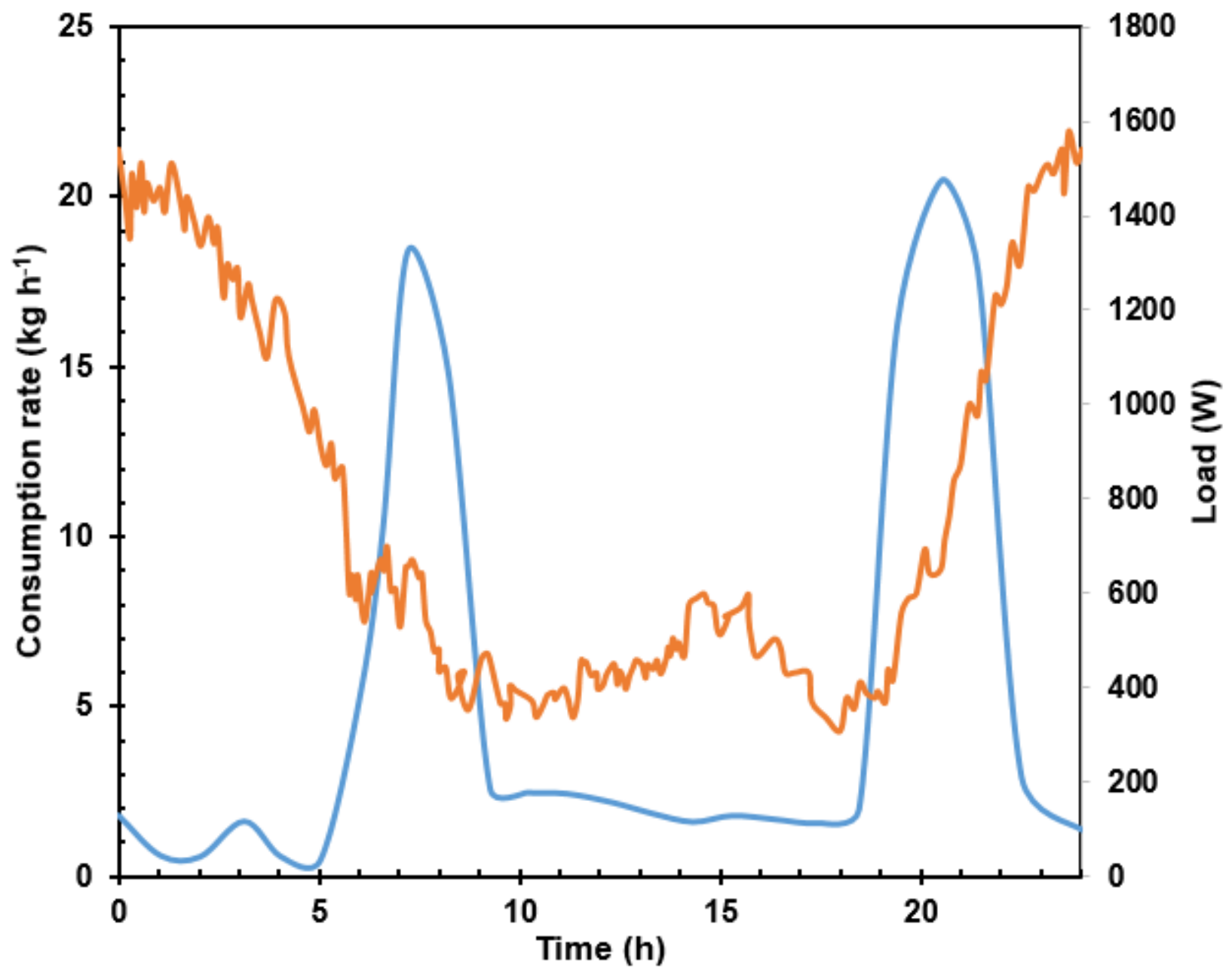

Figure 10

Daily average hot water and alternative current electricity consumption for domestic household buildings 


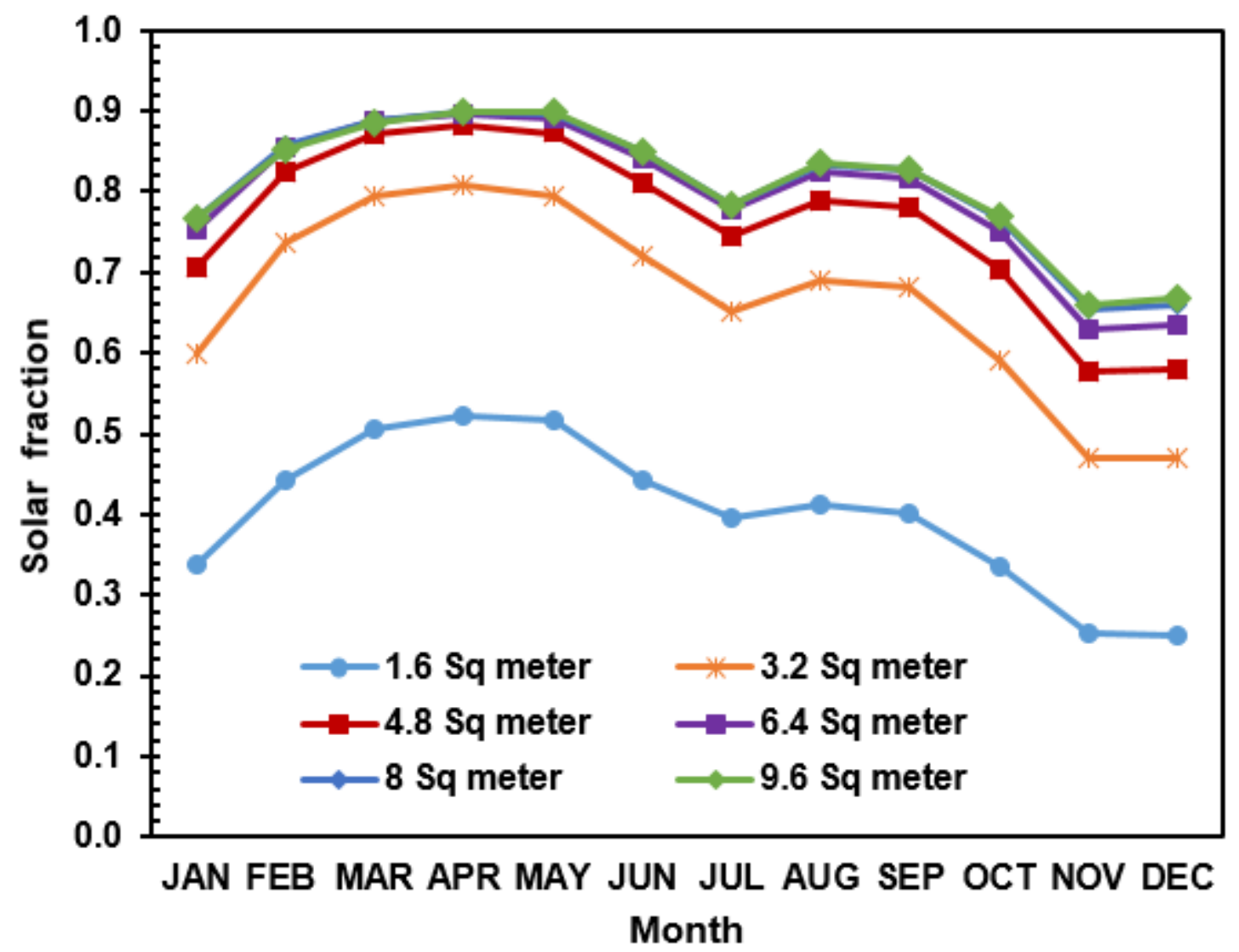

Figure 11

Solar fraction for various PV/STSC area 


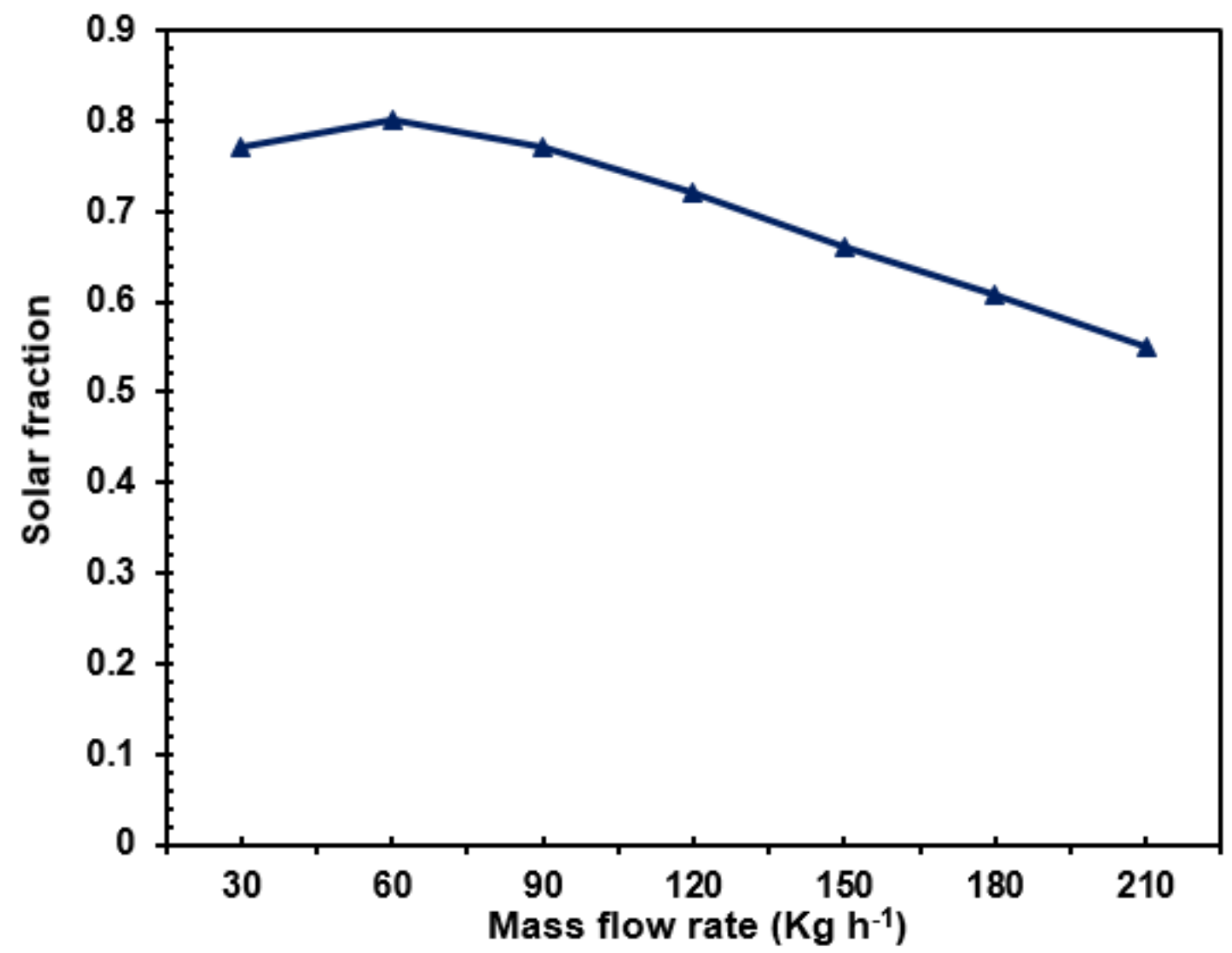

Figure 12

Solar fraction for various mass flow rates of PV/STSC area 


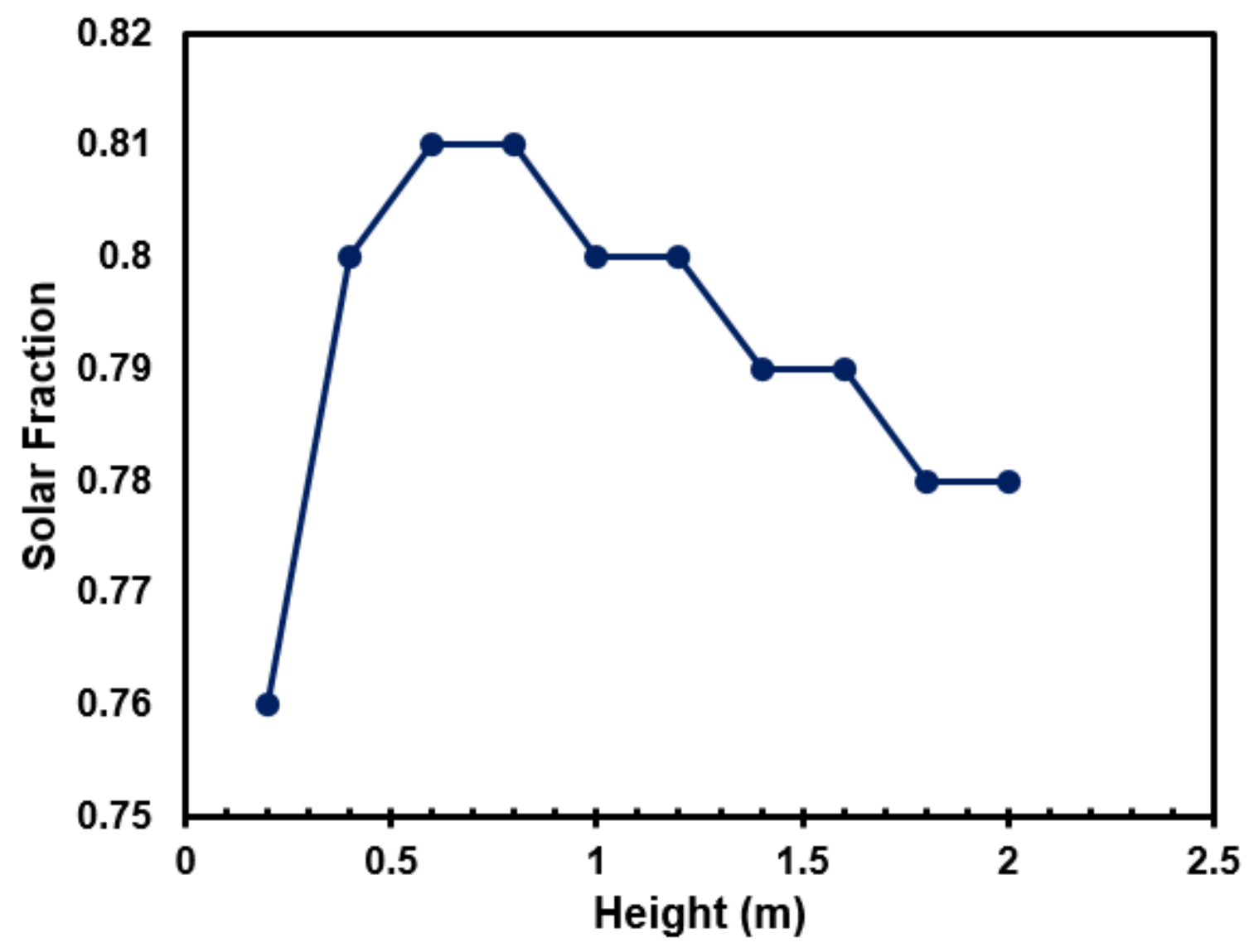

Figure 13

Solar fraction for the height of TES system 


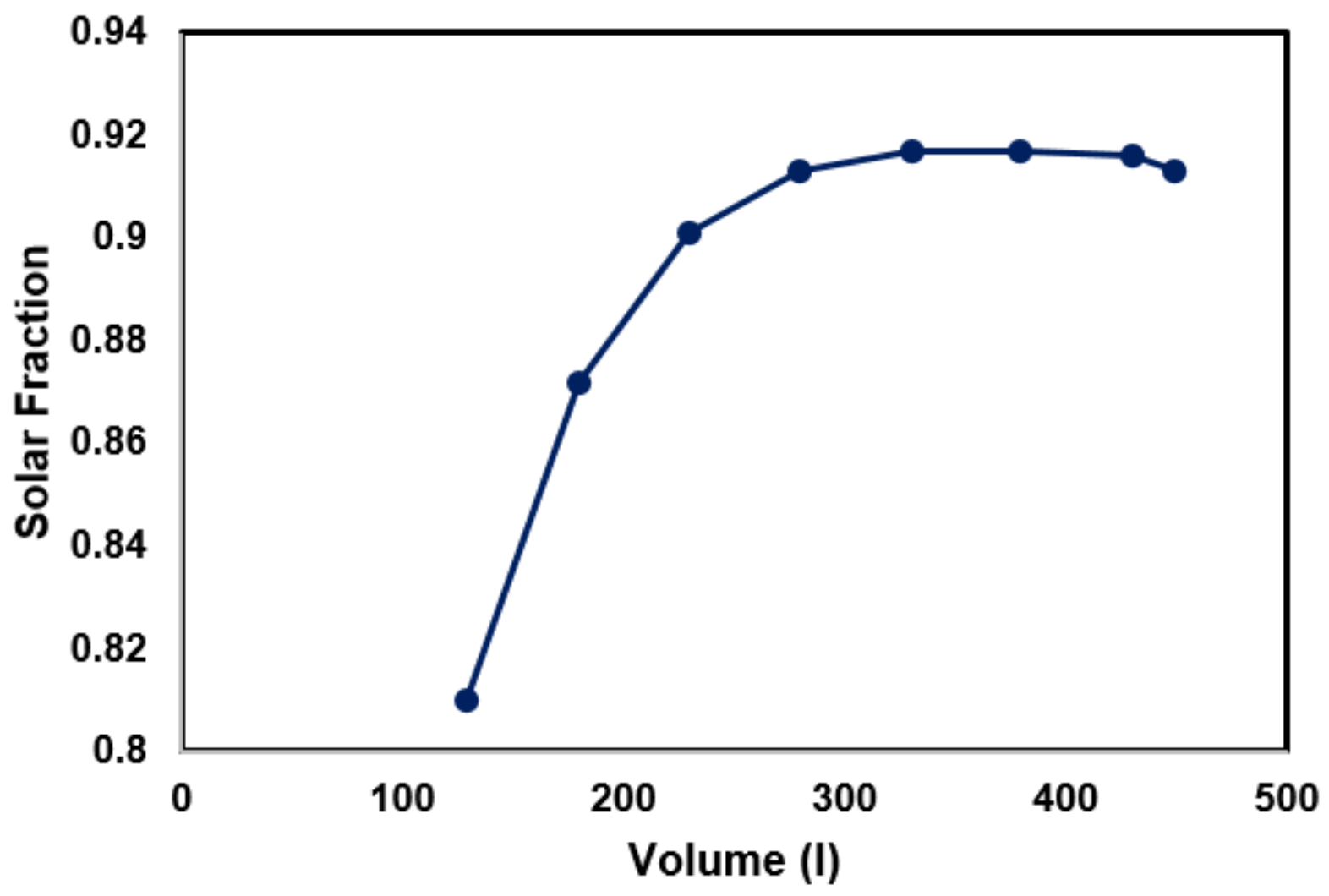

Figure 14

Solar fraction for the volume of TES system 


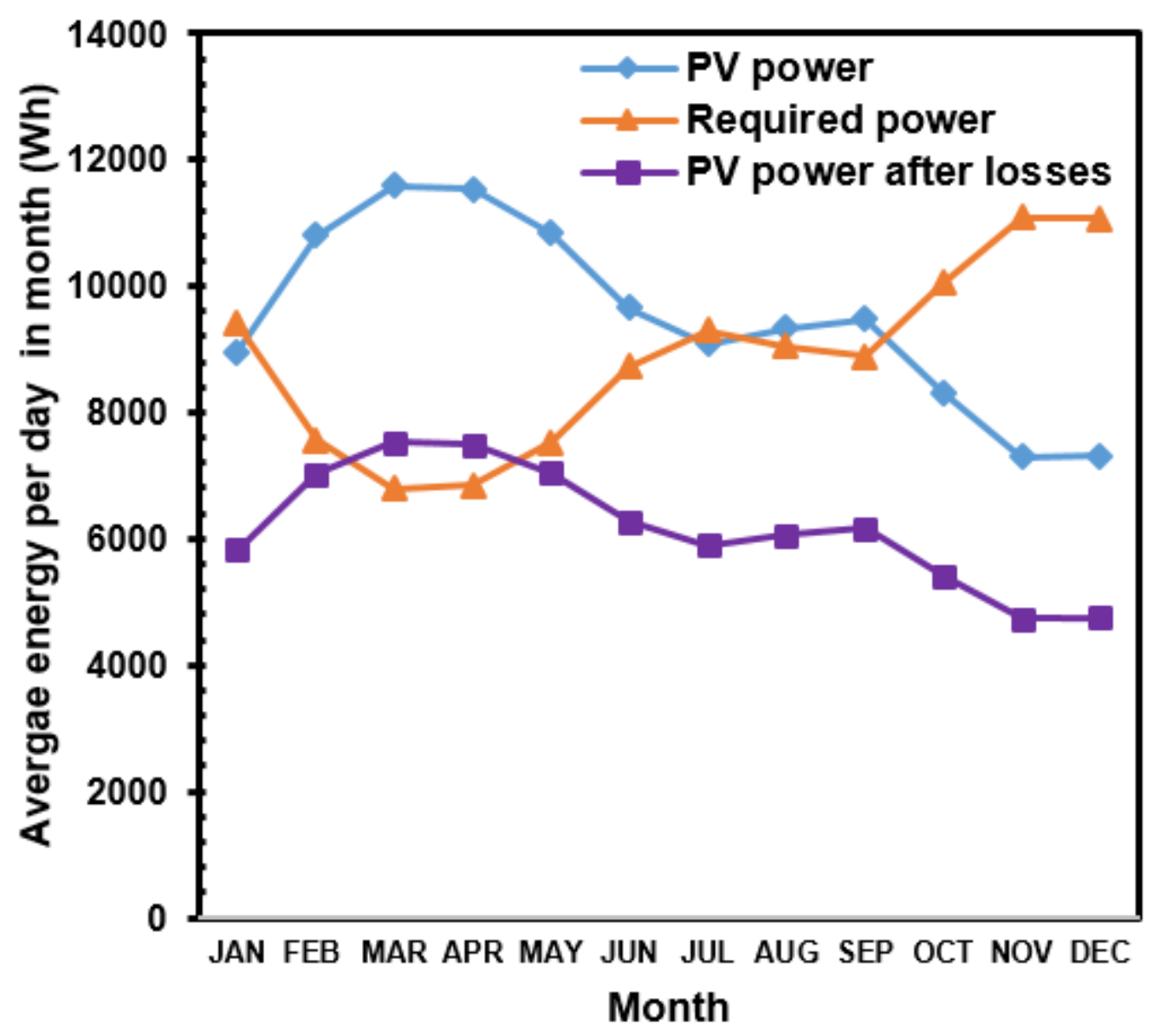

Figure 15

Power from PV/STSC and electricity demand for the various month 